\title{
Analisis Faktor - Faktor yang Mempengaruhi Price Earning Ratio pada Perusahaan Manufaktur yang Listing di BEI
}

\author{
Oktavia Komala Sari ${ }^{1}$ \\ Fakultas Ekonomi dan Bisnis \\ Universitas Mataram, Indonesia
}

\author{
Lilik Handajani ${ }^{2}$ \\ Fakultas Ekonomi dan Bisnis \\ Universitas Mataram, Indonesia
}

\section{Endar Pituringsih ${ }^{3}$ \\ Fakultas Ekonomi dan Bisnis \\ Universitas Mataram, Indonesia}

\begin{abstract}
Surel : oktaviakomala@gmail.com
ABSTRAK

Penelitian ini bertujuan untuk melakukan analisis terhadap faktor apa saja yang dapat mempengaruhi Price Earning Ratio (PER). Faktor yang dianggap dapat mempengaruhi PER yang digunakan sebagai variabel dalam penelitian ini yaitu antara lain Return On Asset (ROA), Debt To Equity Ratio (DER) Dividen Pay Out Ratio (DPR), dan Tingkat Pertumbuhan Laba. Populasi yang digunakan adalah perusahaan manufaktur yang listing di BEI periode 2016-2018. Dengan teknik purposive sampling, diperoleh sebanyak 13 perusahaan yang akan dijadikan sebagai sampel penelitian. Data yang digunakan adalah data sekunder. Untuk melihat pengaruh variabel independen terhadap variabel dependen dilakukan uji analisis regresi linier berganda yang sebelumnya dilakukan uji asumsi klasik. Berdasarkan hasil penelitian diketahui bahwa secara parsial didapatkan hasil bahwa ROA, DPR, dan Tingkat Pertumbuhan Laba masing masing berpengaruh signifikan terhadap PER sedangkan DER tidak berpengaruh signifikan terhadap PER.
\end{abstract}

Kata Kunci: PER; ROA; DER; DPR; Tingkat Pertumbuhan Laba.

\section{Analysis of Factors Affecting the Price Earning Ratio in Manufacturing Companies listing on the IDX}

\section{ABSTRACT}

This study aims to analyze what factors can affect the Price Earning Ratio (PER). Several factors that are considered to be able to influence PER which is used as a variable in this study, namely Return On Asset (ROA), Debt To Equity Ratio (DER), Dividend Pay Out Ratio (DPR), and Profit Growth Rate. . The population used is manufacturing companies listed on the IDX for the 2016-2018 period. With the purposive sampling technique, obtained 13 companies that will be used as research samples. The data used are secondary data. To see the effect of the independent variable on the dependent variable, multiple linear regression analysis tests were carried out which previously carried out the classical assumption test. Based on the results of the study, it is known that partially the results show that ROA, DPR, and Profit Growth Rate respectively have a significant effect on PER while DER has no significant effect on PER.

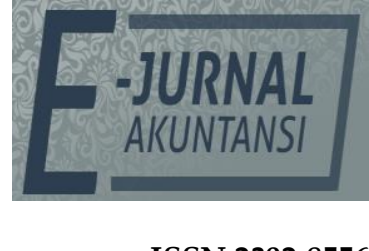

e-ISSN 2302-8556

Vol. 30 No. 12

Denpasar, Desember 2020

Hal. 3220-3239

DOI:

10.24843/EJA.2020.v30.i12.p18

PENGUTIPAN:

Sari, O.K., Handajani, L., \& Pituringsih, E. (2020). Analisis Faktor - Faktor yang Mempengaruhi Price Earning Ratio pada Perusahaan

Manufaktur yang Listing di BEI. E-Jurnal Akuntansi, 30(12), 3220-3239

RIWAYAT ARTIKEL: Artikel Masuk: 16 Oktober 2020 Artikel Diterima: 14 Desember 2020

Keywords: $\quad$ PER; ROA; DER; DPR; Profit Growth Rate.

Artikel dapat diakses : https://ojs.unud.ac.id/index.php/Akuntansi/index 


\section{PENDAHULUAN}

Investasi merupakan suatu kegiatan penanaman modal yang dilakukan baik secara langsung maupun tidak langsung dengan harapan bahwa penanam modal akan memperoleh keuntungan dari kegiatan penanaman modal yang dilakukan tersebut. Ada beberapa jenis investasi yang dapat dilakukan oleh para investor baik investasi yang memiliki resiko yang cenderung tinggi maupun investasi yang cenderung memiliki resiko yang rendah (Ali, 2012). Adapun jenis investasi yang memiliki resiko rendah adalah antara lain dengan melakukan investasi dalam bentuk obligasi ataupun deposito, sedangkan investasi yang cenderung memiliki resiko yang tinggi adalah investasi dalam bentuk saham.

Investasi dalam saham merupakan investasi beresiko tinggi, dimana investor dapat memperoleh keuntungan yang banyak dan sebaliknya bisa menderita kerugian yang tidak sedikit (Ali, 2012). Oleh karena itu, seorang investor dituntut untuk jeli dan harus semakin berhati-hati dalam pengambilan keputusan investasinya serta selalu menganalisis terlebih dahulu informasi atas saham-saham yang akan dibelinya. Informasi ini dianggap sebagai sinyal bagi para investor yang dapat memberikan petunjuk tentang bagaimana manajemen memandang prospek perusahaan. Hal ini sesuai dengan Signalling theory yang diungkapkan oleh Brigham \& Houstan (2011:186) yang mengatakan bahwa informasi mengenai apa yang sudah dilakukan oleh manajemen untuk merealisasikan keinginan pemilik adalah sinyal yang dapat memberikan petunjuk bagi para investor dalam pengambilan keputusan investasi.

Menurut Ali (2012) salah satu rasio yang banyak digunakan oleh investor untuk pengambilan keputusan investasi saham adalah Price Earning Ratio (PER). PER merupakan rasio antara harga per lembar saham dengan laba bersih per sahamnya (EPS). PER juga menunjukkan indikasi tentang adanya masa depan perusahaan. Menurut (Hmieleski \& Corbett, 2008) Sartono (2001:106), PER diartikan sebagai indikator kepercayaan pasar terhadap prospek pertumbuhan perusahaan sehingga banyak pelaku pasar modal menaruh perhatian terhadap pendekatan PER tersebut. Alasan utama mengapa price earning ratio digunakan dalam analisis harga saham adalah karena PER akan memudahkan dan membantu para analis dan investor dalam penilaian saham, di samping itu PER juga dapat membantu para analis untuk memperbaiki judgement karena harga saham pada saat ini merupakan cermin prospek perusahaan di masa yang akan datang. Dibanding dengan metode arus kas, metode ini memiliki kelebihan antara lain karena memudahkan dan kepraktisan serta adanya standar yang memudahkan pemodal untuk melakukan perbandingan penilaian terhadap perusahaan yang lain di industri yang sama (Sartono \& Munir, 1997).

Model PER ini lebih sering digunakan dalam penilaian saham, maka melakukan analisis terhadap faktor-faktor apa saja yang mempengaruhi PER dengan mengetahui seberapa jauh faktor-faktor tersebut mempengaruhi PER adalah sangat penting yang antara lain seperti yang dikemukakan oleh Weston (1990) dimana faktor tersebut antara lain adalah ROA (Return On Asset), DER (Debt To Equity Ratio), DPR (Dividen pay out Ratio) dan tingkat pertumbuhan laba. Hingga saat ini telah cukup banyak peneliti yang melakukan penelitian untuk melihat pengaruh dari beberapa variable seperti ROA (Return On Asset), DER (Debt To Equity Ratio), DPR (Dividen pay out Ratio) dan tingkat pertumbuhan laba 
terhadap PER, Namun, diantara penelitian tersebut masih terdapat hasil yang tidak konsisten dari penelitian-penelitian terdahulu (research gap).

Berdasarkan data pada Bursa Efek Indonesia Perusahaan Manufaktur digolongkan menjadi 3 sektor yaitu Basic Industry And Chemicals (Industri Dasar dan Kimia), Miscellaneous Industry (Aneka Industri), Consumer Goods Industry (Industri Barang Konsumsi). Berikut ini disajikan Nilai PER perusahaan manufaktur dari tahun 2016 - 2018 yang dikutip dari www.idx.co.id.

Tabel 1. Nilai PER Perusahaan Manufaktur Tahun 2016 - 2018

\begin{tabular}{lccc}
\hline \multirow{3}{*}{ Tahun } & \multicolumn{3}{c}{ Perusahaan Manufaktur } \\
\cline { 2 - 4 } & $\begin{array}{c}\text { Basic Industry And } \\
\text { Chemicals (Industri } \\
\text { Dasar dan Kimia) }\end{array}$ & $\begin{array}{c}\text { Miscellaneous } \\
\text { Industry (Aneka } \\
\text { Industri) }\end{array}$ & $\begin{array}{c}\text { Consumer Goods Industry } \\
\text { (Industri Barang } \\
\text { Konsumsi) }\end{array}$ \\
\hline 2016 & 14.32 & 13.54 & 18.77 \\
2017 & 12.88 & 5 & 18.48 \\
2018 & 13.74 & 16.15 & 24.94 \\
\hline
\end{tabular}

Sumber: Data Penelitian, 2020

Dari hasil pengumpulan data yang didapat pada website www.idx.co.id pada Tabel 1, didapatkan hasil yang tidak sama selama tiga tahun terakhir dimana tingkat PER tidak selalu mengalami peningkatan disetiap tahunnya karena pada tahun 2017 tingkat pertumbuhan PER lebih rendah dibandingkan tahun 2016 di mana untuk tahun 2017 PER pada industri dasar kimia hanya 12.88 sedangkan tahun 2016 sebesar 14,32, untuk aneka industri tahun 2017 nilai PERnya hanya 5 sedangkan tahun 2016 sebesar 13,54 dan untuk industri barang konsumsi tahun 2017 nilai PERnya 18,44 dan tahun 2016 sebesar 18,77 meskipun selanjutnya mengalami peningkatan di tahun 2018. Pada tahun 2018 nilai PER untuk industri dasar kimia sebesar 13,74, aneka industri sebesar 16,15 dan industri barang konsumsi sebesar 24,94 dimana nilai PER tersebut seluruhnya lebih tinggi dibandingkan dengan tahun sebelumnya yaitu tahun 2017 yang artinya pada tahun 2018 PER pada perusahaan manufaktur mengalami peningkatan dari tahun sebelumnya.

Di dalam penelitian yang dilakukan oleh Sijabat at al., (2018) terkait Pengaruh DPR, DER, ROA dan ROE Terhadap Price Earning Ratio Pada Perusahaan Manufaktur dikatakan bahwa PER setiap tahunnya cenderung mengalami peningkatan dimana dikatakan bahwa pada Tahun 2014, PER meningkat sebesar 21,04 persen dibandingkan tahun 2013 dan Pada tahun 2015 juga demikian, PER meningkat sebesar 18,68 persen dibanding tahun sebelumnya. Namun, hal ini tidak sejalan dengan hasil pengumpulan data yang dilakukan dari tahun 2016 - 2018 dimana didapatkan hasil bahwa PER setiap tahunnya tidak cenderung selalu mengalami peningkatan melainkan cenderung bersifat fluktuatif yang artinya nilai PER pada perusahaan manufaktur dapat mengalami peningkatan maupun penurunan setiap tahunnya. Fenomena inilah yang melatarbelakangi dilakukannya analisis terhadap faktor - faktor apa saja yang mempengaruhi Price Earning Ratio itu sendiri sehingga dapat mengalami peningkatan maupun penurunan di setiap tahunnya.

Berdasarkan uraian latar belakang dan adanya fenomena terkait tingkat pertumbuhan PER yang tidak selalu konsisten meningkat setiap tahunnya serta adanya hasil yang tidak konsisten antara penelitian yang satu dengan penelitian 
yang lain terkait pengaruh dari beberapa faktor fundamental terhadap PER, maka dilakukan penelitian kembali terkait analisis terhadap faktor - faktor yang mempengaruhi Price Earning Ratio. Selain itu, pentingnya peran price earning ratio dalam memberikan analisis terkait keberlangsungan hidup atau masa depan dari perusahaan maka melakukan analisis terhadap faktor - faktor apa saja yang dapat mempengaruhi Price earning ratio ini dianggap sangat penting. Adapun perbedaan antara penelitian ini dengan beberapa penelitian terdahulu adalah penelitian ini menggunakan waktu penelitian yang lebih terkini yaitu tahun 2016-2018. Alasan menggunakan perusahaan manufaktur yang listing di BEI pada periode tahun 2016-2018 karena pertumbuhan ekonomi di Indonesia sangat dipengaruhi oleh sektor industri manufaktur.

Munawir (2002:269), "Return On Asset merefleksikan seberapa banyak perusahaan telah memperoleh hasil atas sumber daya keungan yang ditanamkan oleh perusahaan". Rasio ROA ini sering dipakai manajemen untuk mengukur kinerja keuangan perusahaan dan menilai kinerja operasional dalam memanfaatkan sumber daya yang dimiliki perusahaan, disamping perlu mempertimbangkan masalah pembiayaan terhadap aktiva tersebut. Nilai ROA yang semakin mendekati 1, berarti semakin baik profitabilitas perusahaan karena setiap aktiva yang ada dapat menghasilkan laba. Penggunaan signalling theory dapat berupa informasi terkait ROA atau tingkat pengembalian terhadap aset atau juga seberapa besar laba yang didapat dari aset yang digunakan, dengan demikian jika ROA tinggi maka akan menjadi sinyal yang baik bagi para investor, karena dengan ROA tinggi menunjukkan kinerja perusahaan tersebut baik maka investor akan tertarik untuk menginvestasikan dananya yang berupa surat berharga atau saham. Permintaan saham yang banyak maka harga saham akan meningkat (Feri, 2013). Menurut penelitian yang dilakukan oleh Safitri (2013), Agustin (2013), dan Dianti (2016) didapatkan hasil bahwa ROA berpengaruh positif terhadap PER. Selain itu, penelitian yang dilakukan oleh Hayati (2010) juga mendapatkan hasil yang serupa dimana ROA berpengaruh positif signifikan terhadap PER. Berdasarkan uraian maka dapat dikatakan bahwa Hipotesis Pertama dalam penelitian ini adalah sebagai berikut.

$\mathrm{H}_{1}$ : ROA berpengaruh positif terhadap Price Earning Ratio.

Debt to equity ratio (DER) merupakan tingkat penggunaan hutang (leverage) terhadap total shareholder's equity yang dimiliki oleh masing-masing perusahaan (Ang, 1997). Rasio ini menunjukkan komposisi atau struktur modal dari total pinjaman (hutang) terhadap total modal yang dimiliki perusahaan. Semakin tinggi DER menunjukkan komposisi total hutang (jangka pendek dan jangka panjang) semakin besar dibanding dengan total modal sendiri, sehingga berdampak semakin besar beban perusahaan terhadap pihak luar (kreditur).

Menurut penelitian yang dilakukan oleh Hayati (2010) terkait DER menyatakan bahwa DER berpengaruh negatif signifikan terhadap PER. Sedangkan penelitian yang dilakukan oleh Yumettasari, et al., (2008) menyatakan bahwa DER berpengaruh positif signifikan terhadap PER. DER itu sendiri merupakan rasio yang digunakan untuk mengukur tingkat leverage terhadap total shareholders equity yang dimiliki perusahaan. Semakin besar DER menunjukkan semakin besar biaya hutang yang harus dibayar perusahaan sehingga profitabilitas akan berkurang. Hal ini menyebabkan hak para 
pemegang saham berkurang, dan akan berpengaruh pada minat investor yang juga akan mempengaruhi harga saham yang semakin menurun.

Adanya perubahan harga saham ini dapat dikaitkan dengan konsep pasar efisien (Efficient Market Theory). Dimana didalam konsep pasar efisien, perubahan harga suatu sekuritas saham di waktu yang lalu tidak dapat digunakan dalam memperkirakan perubahan harga di masa yang akan datang. Perubahan harga saham di dalam pasar efisien mengikuti pola random walk, dimana penaksiran harga saham tidak dapat dilakukan dengan melihat kepada harga-harga historis dari saham tersebut, tetapi lebih berdasarkan pada semua informasi yang tersedia dan muncul dipasar. Informasi yang masuk ke pasar dan berhubungan dengan suatu sekuritas saham akan mengakibatkan kemungkinan terjadinya pergeseran harga keseimbangan yang baru. Jika pasar bereaksi dengan cepat dan akurat terhadap suatu informasi yang masuk dan segera membentuk harga keseimbangan yang baru, maka kondisi pasar yang seperti ini yang disebut dengan pasar efisien (Jogiyanto, 2013). Berdasarkan uraian maka dapat dikatakan bahwa Hipotesis Kedua dalam penelitian ini adalah sebagai berikut.

$\mathrm{H}_{2}$ : DER berpengaruh positif terhadap Price Earning Ratio.

Menurut Husnan (2005:113) dalam Ali (2012) Dividen payout merupakan perbandingan antara dividen per lembar saham dengan laba per lembar saham. Dengan demikian, dapat dikatakan bahwa perusahaan hanya bisa membagikan dividen semakin besar jika perusahaan mampu menghasilkan laba yang semakin besar pula. Namun, jika laba yang diperoleh besarnya tetap, perusahaan tidak bisa membagikan dividen yang makin besar karena hal ini berarti bahwa perusahaan akan membagikan modalnya sendiri. Informasi terkait besarnya dividen yang dibagikan oleh suatu perusahaan ini bisa dikaitkan dengan Teori Sinyal (Signalling theory) dimana menurut Brigham \& Houston (2010) mengatakan bahwa Teori sinyal adalah teori yang mengatakan bahwa investor menganggap perubahan dividen sebagai sinyal dari perkiraan pendapatan manajemen. Dengan didasarkan pada premis bahwa manajemen tahu lebih banyak tentang keuangan masa depan perusahaan dibandingkan pemegang saham, sehingga dividen memberi sinyal prospek perusahaan di masa depan. Penurunan dividen merupakan sinyal yang diharapkan dan manajer yang percaya teori sinyal akan sadar keputusan dividen dapat mengirimkan pesan kepada investor (Gallagher \& Andrew 2014) dalam (Ioaddakhil, 2014).

Pada penelitian yang telah dilakukan olehWhitbeck-Kisor terkait Dividen Payout Ratio Ali (2012) didapatkan hasil bahwa dividen payout ratio berpengaruh positif terhadap price earning ratio, yang berarti bahwa semakin tinggi DPR-nya maka akan semakin tinggi pula nilai PER-nya apabila variabel yang lain dianggap konstan. Dividen Pay out ratio itu sendiri adalah persentase dividen yang dibagikan kepada pemegang saham dari laba bersih setelah pajak yang dihasilkan oleh perusahaan atau entitas. Selain itu, Sunjaya \& Barlian (2002) menyatakan bahwa pengertian rasio pembayaran dividen (dividend payout ratio) adalah persentase dari setiap rupiah yang dihasilkan dibagikan kepada pemilik dalam bentuk tunai dihitung dengan membagi dividen kas per saham dengan laba per saham. Pendapat lain mengemukakan bahwa Dividend Payout Ratio adalah perbandingan antara dividen yang dibayarkan dengan laba bersih yang 
didapatkan dan biasanya disajikan dalam bentuk persentase. Semakin tinggi dividend payout ratio akan menguntungkan para investor tetapi dari pihak perusahaan akan memperlemah internal financial karena memperkecil laba ditahan. Tetapi sebaliknya dividend payout ratio semakin kecil akan merugikan para pemegang saham dan internal finansial perusahaan semakin kuat (Gitosudarmo, 1992). Adapun berdasarkan hasil penelitian Dianti (2016) didapatkan hasil bahwa dividend payout ratio tidak berpengaruh signifikan terhadap price earning ratio pada Indeks Kompas 100. Berdasarkan uraian maka dapat dikatakan bahwa Hipotesis Ketiga dalam penelitian ini adalah sebagai berikut.

$\mathrm{H}_{3}$ : DPR berpengaruh positif terhadap Price Earning Ratio.

Tingkat pertumbuhan laba yang akan diteliti didalam penelitian ini adalah tingkat pertumbuhan laba per lembar saham (Earning per share/EPS). Para pemegang saham dan calon pemegang saham lebih cenderung untuk tertarik akan informasi EPS ini, hal ini desebabkan karena EPS menyajikan informasi berapa jumlah rupiah yang akan diperoleh untuk setiap lembar saham. Semakin besar EPS maka akan semakin besar jumlah nominal atau rupiah yang akan diterima untuk setiap lembar sahamnya, demikian sebaliknya. Besarnya EPS suatu entitas atau perusahaan dapat menjadi tolak ukur bagi para pemegang saham atau calon pemegang saham bahwa entitas tersebut berhasil dalam menjalankan usahanya.

Tingkat pertumbuhan laba atau Earning growth berpengaruh langsung pada Price Earning Ratio dan ini sejalan dengan penelitian yang dilakukan oleh Dianti (2016) menyatakan bahwa return on asset, earning growth dan earning variability secara parsial berpengaruh signifikan terhadap price earning ratio pada Indeks Kompas 100, . Namun dalam penelitian yang dilakukan oleh Ali (2012) dikatakan bahwa current ratio dan pertumbuhan laba berpengaruh negatif dan signifikan terhadap price earning ratio. Bila harga saham mencerminkan kapitalisasi dari laba yang diharapkan dimasa mendatang, maka peningkatan laba akan meningkatkan harga saham dan total kapitalisasi pasar. Bila investor yakin bahwa tingkat perrtumbuhan laba dari perusahaan tersebut atau entitas tersebut adalah terdukung baik, maka PER dari perusahaan tersebut atau entitas tersebut akan meningkat. Laba itu sendiri merupakan cerminan dari kinerja manajemen perusahaan, karena laba merupakan salah satu ukuran keberhasilan dari perusahaan. Semakin tinggi laba yang dihasilkan oleh perusahaan maka kinerja dari manajemen perusahaan dianggap semakin bagus dan sebaliknya semakin rendah laba yang dihasilkan maka manajemen seringkali dianggap gagal dalam mengelola perusahaan. Oleh sebab itu, dapat dikatakan bahwa laba dan segala sesuatu yang terjadi di perusahaan sangat tergantung dari kinerja manajemen dan pilihan - pilihan kebijakan manajemen, terutama yang berkaitan dengan pendapatan dan beban.

Informasi terkait laba dan kinerja manajemen serta pilihan kebijakan manajemen ini dapat dilihat oleh para investor melalui informasi yang disampaikan dalam laporan keuangan perusahaan. Informasi itu sendiri merupakan unsur penting bagi investor dan pelaku bisnis karena informasi pada hakikatnya menyajikan keterangan, catatan atau gambaran baik untuk keadaan masa lalu, saat ini maupun keadaan masa yang akan datang bagi kelangsungan 
hidup suatu perusahaan dan bagaimana pasaran efeknya. Informasi yang lengkap, relevan, akurat dan tepat waktu sangat diperlukan oleh investor di pasar modal sebagai alat analisis untuk mengambil keputusan investasi. Informasi yang dipublikasikan sebagai suatu pengumuman akan memberikan sinyal bagi investor dalam pengambilan keputusan investasi. Jika pengumuman tersebut mengandung nilai positif, maka diharapkan pasar akan bereaksi pada waktu pengumuman tersebut diterima oleh pasar. Secara garis besar signalling theory erat kaitanya dengan ketersedian informasi (Jogiyanto, 2013). Berdasarkan uraian maka dapat dikatakan bahwa Hipotesis Keempat dalam penelitian ini adalah sebagai berikut.

$\mathrm{H}_{4}$ : Tingkat Pertumbuhan Laba berpengaruh positif terhadap Price Earning Ratio.

\section{METODE PENELITIAN}

Jenis penelitian yang digunakan dalam penelitian ini adalah penelitian asosiatif. Adapun Populasi dalam penelitian ini adalah seluruh perusahaan manufaktur yang terdaftar di Bursa Efek Indonesia (BEI) selama tahun 2016 - 2018. Mengingat luasnya populasi, maka melakukan pembatasan populasi dilakukan dengan membedakan populasi sasaran (target population) dan populasi terjangkau (accesibile population). Adapun sampel pada penelitian ini adalah perusahaan manufaktur yang menjadi sasaran populasi dengan kriteria sebagai berikut, Perusahaan manufaktur yang terdaftar di BEI sejak tahun 2016 dan tetap terdaftar di BEI hingga tahun 2018. Hal ini dimaksudkan untuk mendapatkan data yang berkesinambungan dalam mengolah data. Perusahaan yang dijadikan obyek pengamatan memiliki earning per share positif untuk menghindari price earning ratio yang negatif agar tidak terjadi bias hasil sebagai variabel yang dipilih. Perusahaan melakukan pembagian dividen tunai pada periode tahun penelitian (2016-2018). Satuan mata uang dalam satuan rupiah. Adapun proses dari pengurangan sampel penelitian berdasarkan pada kriteria dapat dilihat pada Tabel 2, berikut.

\section{Tabel 2. Kriteria Pengambilan Sampel}

\begin{tabular}{lc}
\hline \multicolumn{1}{c}{ Keterangan } & Jumlah Sampel \\
\hline $\begin{array}{l}\text { Perusahaan manufaktur yang terdaftar di BEI sejak tahun 2016 dan } \\
\text { tetap terdaftar di BEI hingga tahun 2018. }\end{array}$ & 166 \\
Perusahaan Yang memiliki Earning Per Share Negatif & \\
$\begin{array}{l}\text { Perusahaan Yang Tidak melakukan Pembagian Dividen tunai } \\
\text { secara berturut - turut selama 3 Tahun yaitu periode 2016-2018 }\end{array}$ & (75) \\
Perusahaan yang tidak menggunakan rupiah sebagai satuan mata \\
uang
\end{tabular}

Total Perusahaan yang Menjadi Sampel

13 Perusahaan

Sumber: Data Penelitian, 2020

Menurut Lestari \& Sugiharto (2007: 196), ROA adalah rasio yang digunakan untuk mengukur keuntungan bersih yang diperoleh dari penggunaan aktiva. Dengan kata lain, semakin tinggi rasio ini maka semakin baik produktivitas asset dalam memperoleh keuntungan bersih. Gitman (2003: 65) menyatakan bahwa ROA dapat dihitung dengan menggunakan rumus sebagai berikut. 
ROA $=\underline{\text { Laba Bersih Setelah Pajak }} \times 100 \%$

Total Aktiva

Debt to equity ratio (DER) merupakan tingkat penggunaan hutang (leverage) terhadap total shareholder's equity yang dimiliki oleh masing-masing perusahaan (Ang, 1997). Rasio ini menunjukkan komposisi atau struktur modal dari total pinjaman (hutang) terhadap total modal yang dimiliki perusahaan. Syamsuddin (2001: 54) mengatakan bahwa (DER) dapat dinyatakan sebagai berikut.

DER $=\underline{\text { Total Hutang }}$

\section{Total Ekuitas}

DPR itu sendiri adalah dividen kas tahunan dibagi dengan laba tahunan atau Dividen Per Share dibagi dengan Earning per share. Dimana rasio ini menunjukkan persentase laba perusahaan yang selanjutnya akan dibayarkan kepada para pemegang saham dalam bentuk kas. Husnan (2005:13) dalam Ali (2012) menyatakan bahwa DPR dapat dihitung dengan menggunakan rumus matematika sebagi berikut.

DPR $=\quad$ Dividen Per Lembar Saham

Laba Per Lembar Saham

Tingkat pertumbuhan laba yang akan diteliti didalam penelitian ini adalah tingkat pertumbuhan laba per lembar saham (Earning per share/EPS). Adapun rumus yang dapat digunakan untuk menilai tingkat pertumbuhan laba seperti yang dikutip dalam Ali (2012) adalah sebagai berikut.

Earning Growth = EPSt - EPSt-1

Dimana:

EPSt = laba per lembar saham tahun sekarang

EPS $\mathrm{t}-1=$ laba perlembar saham tahun sebelumnya

PER menunjukkan rasio dari harga saham terhadap earning (Jogiyanto:2003). Rasio ini menunjukkan seberapa besar investor menilai harga dari saham terhadap kelipatan dari earning. Secara matematis menurut Ang (1997) dapat dirumuskan sebagai berikut.

PER $=$ Harga Saham

Earning Per Lembar Saham

Analisis yang dilakukan menggunakan program SPSS (Statistical Package For Social Science). Penelitian dilakukan dengan menggunakan analisis regresi linier berganda. Adapun model regresi linier berganda (multiple regression analysis) yang akan digunakan adalah sebagai berikut.

$$
Y=\alpha+\beta 1 X 1+\beta 2 X 2+\beta 3 X 3+\beta 4 X 4+\ldots \ldots+\varepsilon
$$

Keterangan:

$$
\begin{aligned}
& \mathrm{Y}=\text { Price Earning Ratio (PER) } \\
& \mathrm{X} 1=\text { Return on Asset }(\mathrm{ROA}) \\
& \mathrm{X} 2=\text { Debt to Equity Ratio (DER) } \\
& \mathrm{X} 3=\text { Dividend Payout Ratio (DPR) } \\
& \mathrm{X} 4=\text { Tingkat Pertumbuhan Laba } \\
& \beta 1-\beta 6=\text { Koefisien Regresi } \\
& \varepsilon=\text { error term }
\end{aligned}
$$


Sebelum menggunakan metode regresi berganda, perlu dilakukan pengujian asumsi klasik terlebih dahulu agar dapat dilakukan uji kelayakan model pada tahap berikutnya. Uji asumsi klasik terbagi atas Uji Normalitas, Uji Multikolinieritas dan Uji Heteroskedastisitas.

Pengujian selanjutnya adalah pengujian hipotesis untuk mengetahui hubungan ROA, DPR, DER dan Pertumbuhan Laba (Earning Growth) dengan PER. Pengujian hipotesis dapat menggunakan pengujian signifikan parameter individual (uji t), menguji koefesian regresi simultan (uji F) dan koefisien Determinan (Uji R²).

\section{HASIL DAN PEMBAHASAN}

Uji normalitas dalam penelitian ini menggunakan analisis grafik dan analisis satatistik. Analisis grafik yang digunakan untuk menguji normalitas data dalam penenlitian ini menggunakan grafik histrogram dan probability plot. Seperti yang tampak pada Gambar 1, sebagai berikut.

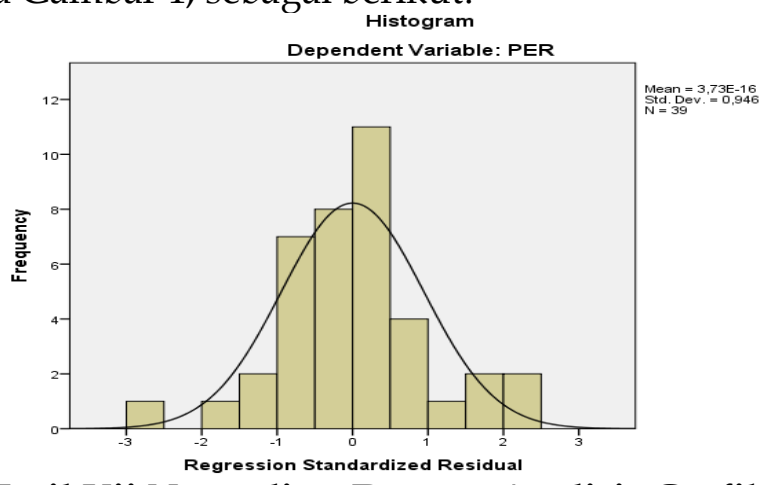

Gambar 1. Hasil Uji Normalitas Dengan Analisis Grafik Histrogram Sumber: Data Penelitian, 2020

Dengan melihat tampilan grafik histrogram, pada Gambar 1, menunjukkan pola data terdistribusi secara normal, karena bentuk kurva pada histrogram memiliki bentuk seperti lonceng. Namun, apabila dilihat grafik histrogram memberikan pola yang sedikit menceng ke kiri, sehingga variabel penganggu atau residual pola data dikatakan mendekati distribusi normal. Kemudian untuk lebih memastikan hasil analisis, uji normalitas penelitian ini juga melihat dengan normal probability plot. Grafik normal probability plot mengambarkan bahwa data mendekati distribusi normal. Pada Gambar terlihat data menyebar disekitar diagonal dan mengikuti arah garis atau grafik histrogramnya. Meskipun data sedikit keluar garis tetapi kemudian mengikuti kembali garis diagonalnya, data observasi penelitian ini dikatakan mendekati distribusi normal. Uji normalitas baik dengan menggunakan grafik histrogram maupun grafik normal probability plot menyatakan bahwa data penelitian ini mendekati distribusi normal. Berikut ini hasil uji normalitas terlihat pada grafik normal probability plot. 


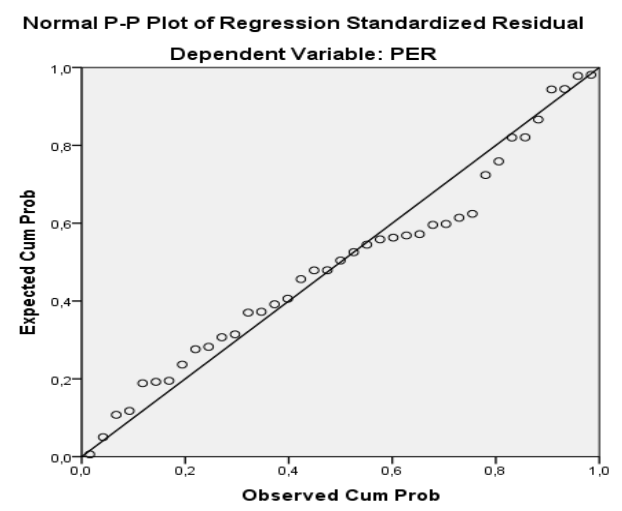

Gambar 2. Hasil Uji Normalitas Dengan Analisis Grafik Probability Plot Sumber: Data Penelitian, 2020

Uji multikolinearitas bertujuan untuk menguji apakah dalam model regresi ditemukan adanya korelasi antara variabel bebas (independen). Model regresi yang baik seharusnya tidak terjadi korelasi antar variabel independen. Jika variabel independen saling berkorelasi, maka variabel-variabel ini tidak ortoghonal. Variabel ortoghonal adalah variabel independen yang nilai korelasi antara sesama variabel independen sama dengan nol. Untuk mendeteksi adanya multikolinearitas salah satunya dengan menggunakan nilai tolerance dan variance inflaction factor (VIF). Apabila nilai tolerance lebih besar dari $0,10(>0,10)$ dan nilai VIF lebih kecil dari $10(<10)$ maka tidak terjadi multikolinearitas (Ghozali, 2006: 91). Dalam penelitian ini uji multikolinearitas dengan perhitungan koefisien (a) seperti pada table berikut.

Dengan menggunakan perhitungan koefisien (a), dalam Tabel 3, hasil perhitungan nilai tolerance sebesar 0,592 atau 59,2\% untuk ROA, 0,703 atau 70,3\% untuk DER, 0,823 atau 82,3\% untuk DPR dan 0,974 atau 97,4\% untuk EG atau tingkat pertumbuhan laba sedangkan untuk nilai Varience Inflation Factor (VIF) adalah sebesar 1,691 untuk ROA, 1,422 untuk DER, 1,214 untuk DPR dan 1,027 untuk EG atau tingkat pertumbuhan laba. Data tersebut menunjukkan bahwa tidak terjadi multikolonieritas, karena nilai tolerance dari variabel bebas lebih dari 10 persen. Dan nilai VIF kurang dari atau sama dengan ( $\leq$ ) 10 sehingga disimpulkan bahwa tidak ada multikolonieritas antar variabel independen dalam model regresi dan data yang digunakan dalam penelitian ini dinyatakan lolos uji asumsi klasik pada uji multikolonieritas serta data yang digunakan layak menggunakan model regresi.

Tabel 3. Uji Multikolinearitas

\begin{tabular}{|c|c|c|c|c|c|c|c|}
\hline \multicolumn{8}{|c|}{ Coefficients $^{a}$} \\
\hline Model & $\begin{array}{l}\text { Unstan } \\
\text { Coefficic }\end{array}$ & dized & $\begin{array}{l}\text { Standardized } \\
\text { Coefficients }\end{array}$ & $\mathrm{t}$ & Sig. & $\begin{array}{r}\text { Coll } \\
\text { St }\end{array}$ & $\begin{array}{l}\text { arity } \\
\text { tics }\end{array}$ \\
\hline 1 & B & $\begin{array}{l}\text { Std. } \\
\text { Error }\end{array}$ & Beta & & & $\overline{\text { Tolerance }}$ & VIF \\
\hline (Constant) & 4,764 & 2,490 & & 1,913 & ,064 & & \\
\hline ROA (X1) & 273 & ,105 & ,340 & 2,610 & ,013 &, 592 & 1,691 \\
\hline $\operatorname{DER}(X 2)$ & 2,267 & 1,984 & 137 & 1,143 & 261 & 703 & 1,422 \\
\hline $\mathrm{DPR}(\mathrm{X} 3)$ & ,274 & ,064 & ,474 & 4,289 & ,000 & 823 & 1,214 \\
\hline $\mathrm{EG}(\mathrm{X} 4)$ & ,123 & ,053 & ,236 & 2,317 & ,027 & ,974 & 1,027 \\
\hline
\end{tabular}

Sumber: Data Penelitian, 2020 
Uji Heterokedastisitas bertujuan untuk menguji apakah dalam model regresi terjadi ketidaksamaan varian dari residual satu pengamatan ke pengamatan yang lain. Pada penelitian ini cara untuk mendeteksi ada atau tidaknya heterokedastisitas adalah dengan melihat grafik plot antara nilai prediksi variabel terikat (ZPRED) dengan residualnya (SRESID) di mana sumbu $Y$ adalah $Y$ yang telah diprediksi dan sumbu $X$ adalah residual ( $Y$ prediksi - $Y$ sesungguhnya) yang telah distandardized (Ghozali, 2011).

Sedangkan dasar pengambilan keputusan untuk uji heterokedastisitas adalah (Ghozali, 2011) yaitu a. Jika ada pola tertentu seperti titik yang ada membentuk pola tertentu yang teratur (bergelombang, melebar, kemudian menyempit), maka mengindikasikan telah terjadi heterokedastisitas. b. Jika tidak ada pola yang jelas serta titik menyebar di atas dan di bawah angka 0 pada sumbu Y, maka tidak terjadi heterokedastisitas. Berikut ini adalah hasil uji heterokedastisitas berasarkan hasil analisis regresi dengan SPSS.

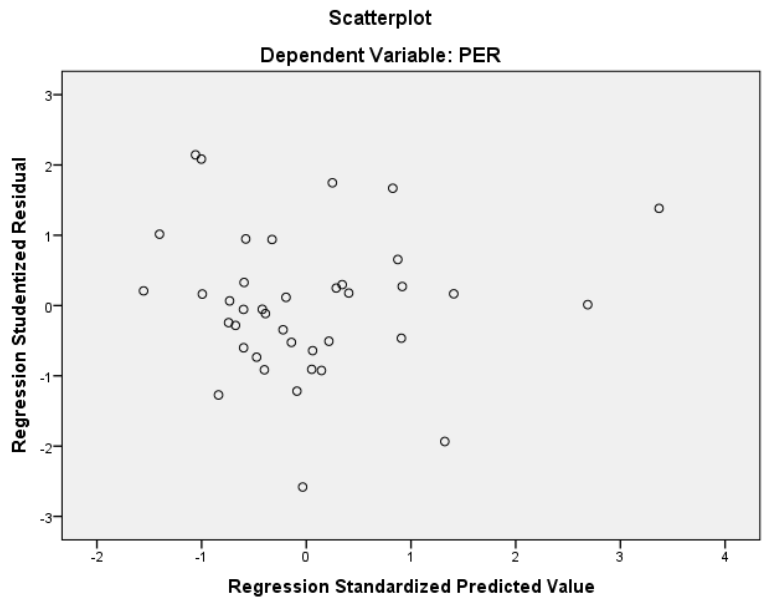

Gambar 3. Hasil Uji Heterokedasitistas

Sumber: Data Penelitian, 2020

Terlihat pola yang tidak jelas dan menyebar tidak menentu, pada Gambar pola titik-titik menyebar di atas dan di bawah angka 0 pada sumbu $Y$, dapat disimpulkan tidak terjadi heteroskedastisitas pada data yang digunakan, artinya terjadi ketidaksamaan varian dari residual satu pengamatan ke pengamatan yang lain. Data yang digunakan lolos uji asumsi klasik uji heteroskedastisitas sehingga data layak digunakan untuk model regresi.

Pengujian hipotesis dilakukan dengan menggunakan analisis regresi linear berganda dengan menggunakan aplikasi SPSS. Setelah dilakukan pengolahan data sekunder pada menu SPSS maka didapatkan hasil seperti pada Tabel 4.

Tabel 4. Hasil Uji Regresi Linear Berganda

\begin{tabular}{lrrr}
\hline \multicolumn{1}{c}{ Variabel } & Coefficients (B) & t-hitung & Signifikansi \\
\hline Konstanta & 4,764 & 1,913 &, 064 \\
ROA(X1) &, 273 & 2,610 &, 013 \\
DER(X2) & 2,267 & 1,143 &, 261 \\
DPR(X3) &, 274 & 4,289 &, 000 \\
EG(X4) &, 123 & 2,317 &, 027 \\
\hline
\end{tabular}

Sumber: Data Penelitian, 2020 
Berdasarkan Tabel 4, maka dapat disusun persamaan regresi Linear Berganda sebagai berikut.

$$
\mathrm{PER}=4,764+0,273 \mathrm{ROA}+2,267 \mathrm{DER}+0,274 \mathrm{DPR}+0,123 \mathrm{EG}+\varepsilon
$$

Uji koefisien determinasi $\left(R^{2}\right)$ dilakukan untuk melihat sejauh mana variabel independen dapat menjelaskan variasi variabel dependen dalam penelitian. Nilai koefisien determinasi adalah antara nol dan satu. Semakin kecil nilai yang ditunjukkan oleh adj $R$-Square maka semakin kecil variasi variabel independen dapat menjelaskan variabel dependen. Adapun hasil koefisien deterninasi dari pengolahan data pada SPSS adalah sebagai berikut.

Tabel 5. Hasil Uji Koefisien Determinasi

\begin{tabular}{lrrrr}
\hline Model & $\mathrm{R}$ & $\mathrm{R}$ Square & Adjusted R Square & $\begin{array}{c}\text { Std. Error of the } \\
\text { Estimate }\end{array}$ \\
\hline 1 &, $811^{\mathrm{a}}$ &, 658 &, 618 & 7,24305
\end{tabular}

Sumber: Data Penelitian, 2020

Berdasarkan Tabel 5, dapat dijelaskan bahwa nilai adjusted koefisien determinasinya adalah sebesar 0,658 atau 65,8 \%. Hal ini menunjukkan bahwa $65,8 \%$ variasi dari PER dapat dijelaskan oleh variabel bebas dalam penelitian ini dan sisanya dapat dijelaskan oleh variabel lain yang tidak dimasukkan dalam penelitian ini. Hal ini menunjukkan bahwa masih terbuka variabel lain selain ROA, DER, DPR dan EG yang dapat berpengaruh terhadap PER baik itu yang berpengaruh signifikan maupun tidak signifikan.

Uji f digunakan untuk mengetahui apakah semua variabel independen yang dimasukkan dalam model mempunyai pengaruh secara bersama-sama terhadap variabel dependen. Uji f dilakukan dengan membandingkan besaran probabilitas value ( $p$ value) dengan taraf signifikansi 5\% $(0,05)$. Kriteria pengujian hipotesis dilakukan dengan membandingkan $\mathrm{f}_{\text {tabel }}$ dengan $\mathrm{f}_{\text {hitung. }}$. Ho ditolak jika $\mathrm{f}_{\text {hitung }} \leq \mathrm{f}_{\text {tabel }}$ dan $\mathrm{H}_{1}$ diterima jika $\mathrm{f}_{\text {hitung }}>\mathrm{f}_{\text {tabel. }}$. Adapun hasi dari uji $\mathrm{F}$ pada SPSS adalah sebagai berikut.

Tabel 6. Hasil Uji Statistik F

\begin{tabular}{ccc}
\hline F-hitung & Signifikansi & Kesimpulan \\
\hline 16,350 &, $000^{\mathrm{b}}$ & Berpengaruh Simultan \\
\hline
\end{tabular}

Sumber: Data Penelitian, 2020

Berdasarkan Tabel 6, dapat dijelaskan bahwa $\mathrm{f}_{\text {hitung }}$ memiliki nilai 16,350 dengan nilai signifikansi 0,000. Nilai $F_{\text {tabel }}$ pada tabel distribusi $F$ (a:0,05; df1: 4; \& df2: 33) adalah sebesar 2,659. Hal ini berarti bahwa $f_{\text {hitung memiliki nilai yang }}$ lebih besar dari $\mathrm{f}$ tabel yaitu 2,659 dengan nilai signifikansi yang lebih kecil dari 0,05 hal ini berarti bahwa variabel - variabel bebas dalam penelitian ini secara simultan berpengaruh signifikan terhadap variabel terikat.

Uji $\mathrm{t}$ digunakan untuk mengetahui pengaruh masing-masing variabel independen terhadap variabel dependen. Uji $t$ dilakukan dengan membandingkan antara $\mathrm{t}$ hitung dengan $\mathrm{t}$ tabel. Untuk menentukan nilai $\mathrm{t}$ tabel ditentukan dengan tingkat signifikansi 5\%. Berikut disajikan Tabel data hasil pengujian hipotesis yang menggunakan uji t.

Variabel ROA pada Tabel 7, memiliki nilai $t$ hitung sebesar 2,610 dan nilai signifikansi sebesar 0.013. Jika dibandingkan dengan nilai $t$ table (a: 0,05; df (n-4): 35) adalah 2,03) maka dapat dikatakan bahwa nilai $t_{\text {hitung }}$ ROA lebih besar dari $t$ 
table yaitu 2,03 dengan nilai signifikansi yang lebih kecil dari 0,05. Maka berdasarkan hasil tersebut dapat dikatakan bahwa ROA berpengaruh signifikan terhadap PER. Hal ini berarti hipotesis diterima.

Tabel 7. Hasil Uji Statistik t

\begin{tabular}{lrrr}
\hline \multicolumn{1}{c}{ Variabel } & t-hitung & \multicolumn{1}{c}{ Signifikansi } & Kesimpulan \\
\hline Konstanta & 1,913 &, 064 & \\
ROA(X1) & 2,610 &, 013 & Berpengaruh Signifikan \\
DER(X2) & 1,143 &, 261 & Tidak Berpengaruh \\
DPR $(X 3)$ & 4,289 &, 000 & Berpengaruh Signifikan \\
EG(X4) & 2,317 &, 027 & Berpengaruh Signifikan \\
\hline
\end{tabular}

Sumber: Data Penelitian, 2020

Varibel DER pada Tabel 7, memiliki nilai $t$ hitung 1,143 dan nilai signifikansi sebesar 0,261 yang berarti bahwa nilai $t$ hitung lebih kecil dari $t$ table yaitu 2,03(a: 0,05; df (n-4): 35) adalah 2,03) dengan nilai signifikansi yang lebih besar dari 0,05. Hal ini berarti bahwa varibel DER tidak berpengaruh signifikan terhadap PER. Hal ini berarti Hipotesis ditolak.

Variabel DPR memiliki nilai $t$ hitung sebesar 4,289 dengan nilai signifikansi sebesar 0,000. Jika dibandingkan dengan nilai $t$ tabel yaitu 2,03 (a: 0,05; df (n-4): 35) adalah 2,03) maka nilai $t$ hitung variable DPR lebih besar dari $t$ tabel dengan nilai signifikansi yang lebih kecil dari 0,05. Hal ini berarti Hipotesis Diterima.

Variabel EG atau tingkat pertumbuhan laba pada Tabel 7, memiliki nilai $t$ hitung 2,317 dengan signifikansi 0,027. Jika di bandingkan dengan nilai $t$ tabel yaitu 2,03(a: 0,05; df (n-4): 35) adalah 2,03) maka nilai $t$ hitung EG lebih besar dari $t$ tabel dengan signifikansi yang lebih kecil dari 0,05. Hal ini berarti Hipotesis diterima.

ROA atau Return on asset dapat merefleksikan seberapa banyak perusahaan telah memperoleh hasil atas sumber daya keuangan atau asset yang ditanamkan oleh perusahaan (Munawir 2002:269). Berdasarkan hasil uji t yang dilakukan dalam penelitian ini didapatkan hasil bahwa nilai $t$ hitung ROA lebih besar dari $t$ table yaitu 2,03 dengan nilai signifikansi yang lebih kecil dari 0,05. Berdasarkan hasil tersebut dapat dikatakan bahwa ROA berpengaruh signifikan positif terhadap PER. Hal tersebut berarti bahwa apabila nilai ROA semakin tinggi maka Nilai PER akan ikut meningkat. Penelitian ini sejalan dan memperkuat penelitian yang dilakukan oleh Agustin (2013), Wahyu Hidayat (2013) ,Yusuf (2014) dan Tenaya (2016) di mana hasil penelitian tersebut memberikan kesimpulan bahwa ROA berpengaruh positif signifikan terhadap PER. Sedangkanhasil tak serupa diperoleh Hayati (2010), Sukamdani (2011) dan Adam (2015) yang memberi kesimpulan bahwa ROA berpengaruh negatif dan signifkan terhadap PER.

Return on Asset (ROA) itu sendiri mencerminkan kesanggupan dari perseroan memperoleh return melalui pemaksimalan aktiva milikinya (Tandelilin, 2010:378). Perhitungan ratio ini dilakukan dengan cara membandingkan laba bersih dari perusahaan terhadap total assetnya. Nilai ROA yang meningkat atau naik menunjukkan semakin baiknya kinerja dari perusahaan dan mencerminkan perusahaan menggunakan asetnya semakin efisien dalam menghasilkan laba (Brigham \& Houston, 2011). Nilai ROA yang semakin meningkat akan semakin meningkatkan pula nilai dari perusahaan tersebut yang tentunya akan berimbas pada peningkatan harga saham dan 
naiknya PER. Adanya informasi terkait naiknya nilai ROA dari suatu perusahaan tersebut akan memberikan sinyal yang positif kepada para investor. Hal ini sejalan dengan signalling theory dimana menurut Brigham \& Houstan (2011:186) signalling theory itu sendiri adalah suatu tindakan yang diambil perusahaan untuk memberi petunjuk atau sinyal bagi investor tentang bagaimana manajemen memandang prospek perusahaan. Sinyal ini berupa informasi mengenai apa yang sudah dilakukan oleh manajemen untuk merealisasikan keinginan pemilik. Informasi terkait naik atau turunnya nilai ROA suatu perusahaan dapat dijadikan sinyal bagi para investor dalam proses pengambilan keputusan investasinya.

DER atau Debt to equity Ratio merupakan tingkat penggunaan hutang (leverage) terhadap total shareholder's equity yang dimiliki oleh masing - masing perusahaan (Ang, 1997). Hasil penelitian ini menunjukkan bahwa nilai $t$ hitung lebih kecil dari $t$ table yaitu 2,03 (a: 0,05; df (n-4): 35) adalah 2,03) dengan nilai signifikansi yang lebih besar dari 0,05. Hal ini berarti bahwa varibel DER tidak berpengaruh signifikan terhadap PER. Hasil penelitian ini tidak sejalan dengan penelitian yang dilakukan oleh Yumettasari et al., (2008) yang menyatakan bahwa DER berpengaruh positif signifikan terhadap PER.

Penelitian ini sejalan dan memperkuat penelitian yang dilakukan oleh Hayati (2010) dan Ali (2012) yang menyatakan bahwa DER tidak berpengaruh signifikan terhadap PER. Artinya jika variabel DER meningkat maka nilai PER dari perusahaan tersebut tidak ikut meningkat.

Debt to Equity Ratio (DER) adalah bagian dari ratio solvabilitas yang membandingan total Debt dengan Equity (Martono \& Harjito, 2005). Kenaikan DER akan mengakibatkan risiko perusahaan naik. DER menggambarkan kemampuan perusahaan melunasi hutangnya menggunakan equity. Debt to Equity Ratio membandingkan seluruh utang terhadap equity (Martono \& Harjito, 2005). Rasio ini mencerminkan banyaknya utang dari perusahaan yang dijamin menggunakan modal. Ratio DER yang tinggi mencerminkan utang perseroan yang tinggi. Naiknya DER mengindikasikan bertambahnya utang perusahaan. Bertambahnya utang menyebabkan solvability rendah. Resiko perseroan menjadi relatif tinggi sehingga investasi saham menjadi beresiko. Alhasil, harga dari saham mengalami penurunan dan PER juga turun (Martono \& Harjito, 2005). Adanya perubahan harga saham ini dapat dikaitkan dengan konsep dari pasar efisien (Efficient Market Theory). Dimana didalam konsep pasar efisien, perubahan harga suatu sekuritas saham di waktu yang lalu tidak dapat digunakan dalam memperkirakan perubahan harga di masa yang akan datang. Perubahan harga saham di dalam pasar efisien mengikuti pola random walk, dimana penaksiran harga saham tidak dapat dilakukan dengan melihat kepada harga-harga historis dari saham tersebut, tetapi lebih berdasarkan pada semua informasi yang tersedia dan muncul dipasar. Informasi yang masuk ke pasar dan berhubungan dengan suatu sekuritas saham akan mengakibatkan kemungkinan terjadinya pergeseran harga keseimbangan yang baru. Jika pasar bereaksi dengan cepat dan akurat terhadap suatu informasi yang masuk dan segera membentuk harga keseimbangan yang baru, maka kondisi pasar yang seperti ini yang disebut dengan pasar efisien (Jogiyanto, 2013). 
Menurut Husnan (2005:113) dalam Ali (2012) Dividen payout merupakan perbandingan antara dividen per lembar saham dengan laba per lembar saham. Hasil dari penelitian ini menunjukkan bahwa DPR berpengaruh positif terhadap PER. Dimana jika nilai DPR tinggi maka akan disertai dengan tingginya nilai PER. Hal ini sejalan dengan penelitian yang dilakukan oleh Ali (2012), Arisona (2013), linda (2013) dan Arman (2013) yang memperoleh kesimpulan DPR berpengaruh pengaruh positif dan signifikan terhadap PER namun tidak sejalan dengan penelitian yang dilakukan oleh Rahma (2014), Tenaya (2016) dan Kusumadewi (2016) yang menyimpulkan bahwa DPR berpengaruh postif dan tidak signfikan terhadap PER (Price Earning Ratio).

Perubahan nilai DPR dapat berpengaruh terhadap nilai PER (Husnan, 2001). Kenaikan rasio ini menggambarkan jumlah dividen yang dibagikan oleh perusahaan akan ikut mengalami kenaikan. Adanya informasi terkait naiknya nilai DPR dari suatu perusahaan tersebut akan memberikan sinyal yang positif kepada para investor. Adanya informasi terkait kenaikan jumlah pembayaran dividen oleh perusahaan akan mengakibatkan kenaikan minat investor dalam melakukan investasi terhadap perusahaan tersebut yang artinya hal tersebut dapat mengakibatkan nilai PER dari perusahaan tersebut akan ikut mengalami kenaikan pula. Hal ini sejalan dan memperkuat teori sinyal atau signalling theory dimana menurut Brigham \& Houstan (2011:186) signalling theory itu sendiri adalah suatu tindakan yang diambil perusahaan untuk memberi petunjuk atau sinyal bagi investor tentang bagaimana manajemen memandang prospek perusahaan. Sinyal ini berupa informasi mengenai apa yang sudah dilakukan oleh manajemen untuk merealisasikan keinginan pemilik. Informasi terkait naik atau turunnya nilai DPR yang tentunya berimbas pada nilai dividen yang diberikan suatu perusahaan kepada para pemiliknya dapat dijadikan sinyal bagi para investor dalam proses pengambilan keputusan investasinya.

Tingkat pertumbuhan laba yang diteliti didalam penelitian ini adalah tingkat pertumbuhan laba per lembar saham (Earning per share/EPS). Tingkat pertumbuhan laba atau Earning growth berpengaruh langsung pada Price Earning Ratio.Penelitian ini membuktikan bahwa earning growth memiliki pengaruh positif dan signifikan terhadap price earning ratio. Hasil positif dan signifikan dari koefisien earning growth ini searah dengan teori yang ada yang menyatakan bahwa jika laba perlembar saham pada suatu perusahaan mengalami peningkatan di setiap periodenya maka perusahaan akan mudah menarik minat investor untuk membeli sahamnya, dengan meningkatnya laba perlembar saham maka nilai PER perusahaan juga akan meningkat.

Penelitian ini sejalan dan memperkuat penelitian yang dilakukan oleh Ramadan (2015) dan Digregorio (2014) yang dikutip dari Diantini et al., (2016) dimana didalam penelitian tersebut Digregorio (2014) menyatakan bahwa peningkatan laba perlembar saham di setiap periodenya akan sangat mudah menarik minat investor. Earning growth ini memberikan informasi kepada pihak luar seberapa jauh kemampuan perusahaan meningkatkan laba untuk setiap lembar saham yang beredar. Laba perlembar saham yang terus meningkat menunjukkan tingkat kesejahteraan perusahaan yang baik. Bagi perusahaan yang sedang mengalami gangguan pada keuangan perusahaan, tidak akan mampu memberikan peningkatan pada laba perlembar sahamnya di setiap 
periode. Maka earning growth dinyatakan berpengaruh terhadap PER pada penilaian saham. Penelitian ini tidak sejalan dengan penelitian yang dilakukan oleh Rahma (2014) yang menyatakan bahwa Earning Growth memiliki pengaruh yang negative tidak signifikan terhadap PER (Price Earning Ratio).

Berdasarkan penjelasan dapat dikatakan bahwa penelitian ini mendukung salah satu teori dasar yang digunakan dalam penelitian ini yaitu Signalling theory. signalling theory itu sendiri menurut Brigham \& Houstan (2011:186) adalah suatu tindakan yang diambil perusahaan untuk memberi petunjuk atau sinyal bagi investor tentang bagaimana manajemen memandang prospek perusahaan. Sinyal ini berupa informasi mengenai apa yang sudah dilakukan oleh manajemen untuk merealisasikan keinginan pemilik. Pasar Modal mengantisipasi perusahaan untuk mempertahankan tingkat pertumbuhan laba agar perusahaan dapat tetap menjaga nilai sahamnya (Heidari et. al, 2012), karna apabila investor telah mendapat sinyal atau informasi bahwa perusahaan mampu mempertahankan tingkat pertumbuhan labanya maka Investor akan sanggup untuk membeli saham dengan PER yang tinggi asalkan memiliki pertumbuhan laba yang tinggi.

\section{SIMPULAN}

ROA (Return On Asset) berpengaruh positif terhadap PER (Price Earning Ratio) dimana hal tersebut berarti bahwa apabila nilai ROA suatu perusahaan semakin tinggi atau meningkat maka Nilai PER dari perusahaan tersebut akan ikut meningkat. Nilai ROA yang semakin meningkat ini akan semakin meningkatkan pula nilai dari perusahaan tersebut yang tentunya akan berimbas pada peningkatan harga saham dan naiknya PER.

DER (Debt To equity Ratio) tidak berpengaruh positif terhadap PER (Price Earning Ratio) hal tersebut berarti bahwa apabila nilai DER suatu perusahaan semakin tinggi atau meningkat maka tidak diikuti dengan meningkatnya nilai PER dari perusahaan tersebut. Ratio DER yang tinggi mencerminkan utang perseroan yang tinggi. Naiknya DER mengindikasikan bertambahnya utang perusahaan dan bertambahnya utang perusahaan menyebabkan solvability rendah. Hal ini menyebabkan resiko perseroan menjadi relatif tinggi sehingga investasi saham menjadi beresiko. Alhasil, harga dari saham mengalami penurunan dan PER juga turun.

DPR (Dividen Pay Out Ratio) berpengaruh positif terhadap PER (Price Earning Ratio) yang artinya kenaikan nilai DPR suatu perusahaan akan diikuti pula oleh kenaikan nilai PER. Kenaikan DPR mencerminkan bahwa 1aba perusahaan naik. Kenaikan laba bisa dikarenakan baiknya kinerja perusahaan dan akan mempengaruhi investor untuk menginvestasikan dananya pada saham perusahaaan. Kenaikan dividen yang dibayarkan merupakan sinyal untuk melakukan investasi yang mengakibatkan PER akan naik.

Tingkat pertumbuhan laba (Earning Growth) berpengaruh positif terhadap PER (Price Earning Ratio) yang artinya apabila tingkat pertumbuhan laba suatu perusahaan meningkat maka nilai PER dari perusahaan tersebut pun akan ikut meningkat. Hasil positif dan signifikan dari koefisien earning growth ini searah dengan teori yang ada yang menyatakan bahwa jika laba perlembar saham pada suatu perusahaan mengalami peningkatan di setiap periodenya maka 
perusahaan akan mudah menarik minat investor untuk membeli sahamnya, dengan meningkatnya laba perlembar saham maka nilai PER perusahaan juga akan meningkat.

Penelitian ini selain diharapkan dapat memberikan implikasi terhadap pengembangan ilmu pengetahuan namun juga memiliki keterbatasan dan saran untuk penelitian selanjutnya, yang antara lain: Penelitian ini hanya menggunakan 4 (empat) variabel independen yang dianggap dapat mempengaruhi nilai PER dari suatu perusahaan sedangkan masih ada beberapa faktor lain diluar variabel tersebut yang dapat di jadikan sebagai variabel tambahan untuk dilihat pengaruhnya terhadap PER serta dapat menambahkan variabel moderasi misalnya dengan menggunakan Discretionary Accrual Karena Discretionary accrual itu sendiri merupakan salah satu cara penilaian untuk mendeteksi apakah perusahaan tersebut melakukan praktek manajemen laba atau tidak. Penelitian ini menggunakan alat analisis Regresi Linier Berganda untuk menguji pengaruh beberapa variabel independen terhadapat variabel dependen. Penelitian selanjutnya disarankan untuk lebih mengembangkan model penelitian seperti penggunaan variabel moderasi serta menggunakan alat analisis yang berbeda seperti Moderated Regresion Analysis (MRA).

\section{REFERENSI}

Adam, E. \& Djiumahir. 2015. Variable yang mempengaruhi rasio PER dan dampaknya pada return saham. 31(4):7114 -7128.

Abigael K., Veronika, I. \& Ardiani, I.S. (2008). "Pengaruh Return on Asset, Price Earning Ratio, Earning per Share, Debt to Equity Ratio, Price to Book Value terhadap Harga Saham Manufaktur di BEI". Jurnal Solusi. 7 (4): 75-90.

Ang, Robert. (1997). Buku Pintar Pasar Modal Indonesia, Jakarta : Mediasoft Indonesia.

Agustin, R. S. (2013). Analisis Pengaruh PBV, EPS, DER, dan ROA Terhadap Price Earning Ratio (PER) Pada Perusahaan Pertambangan di Bursa Efek Indonesia Periode 2009 - 2012. JURNAL. Universitas Semarang. Semarang.

Agus S., \& Munir, M. (1997). Pengaruh Kategori Industri terhadap Price Earning Ratio dan faktor-faktor penentunya. Yogyakarta.

Aji, M. N. \& Irene R.D.P. (2012). Analisis FaktorFaktor yang Mempengaruhi Price Earning Ratio (Studi Empiris pada Perusahaan Manufaktur yang Terdaftar di Bursa Efek Indonesia 2007- 2010). Diponogoro Journal of Management. 1 (1): 382-391.

Ali, M. 2012. Analisis factor - factor yang mempengaruhi Price Earning Ratio pada perusahaan manufaktur di Bursa Efek Indonesia. TESIS. Dipublikasikan oleh Universitas Terbuka Jakarta.

Arisona, V. F. (2013). Faktor-Faktor yang Mempengaruhi Price Earning Ratio pada Indeks LQ45 di Bursa Efek Indonesia. Jurnal Ilmu Manajemen Universitas Negeri Surabaya. 1(1): 103-112.

Augusty, F. (2006). Metode Penelitian Manajemen: Pedoman Penelitian Untuk Penulisan Skripsi, Tesis dan Disertasi Ilmu Manajemen. Semarang: Badan Penerbit Universitas Diponegoro. 
Brigham, E. F. \& Houston, J. F. (2011). Dasar-dasar Manajemen Keuangan Buku 1 (Edisi 11). Jakarta: Salemba Empat.

Damayanti, S. \& Achyani, F. (2006). Analisis Pengaruh Investasi, Likuiditas, Profitabilitas, Pertumbuhan Perusahaan, dan Ukuran Perusahaan terhadap Kebijakan Dividen Payout Ratio. Jurnal Akuntansi dan Keuangan. 5(1) : 51-62.

Gitman, J, Laurence. (2003). Principle of Managerial Finance 10. Boston: Pearson Education, Inc.

Gitosudarmo, I. \& Basri. (1992). Manajemen Keuangan. Edisi kedua. Yogyakarta : BPFE Yogyakarta.

E.Fama. (1970). Efficient Capital Markets: A Review Of Theory And Empirical Work. Journal Finance. 383-417.

Faezinia., et.,al. (2012). The Quantitative Study Of Effective Factors On PriceEarning Ratio In Capital Market Of Iran. Interdisciplinary journal of contemporary research in business. 3(1)0.

Ghozali, I. (2006). Aplikasi Analisis Multivariate Dengan Program SPSS. Semarang: Badan Penerbit UNDIP.

Hartono, J. (2000). Teori Portofolio dan Analisis Investasi, BPFE Yogyakarta.

Hasanah, N. (2009). Faktor - Faktor Fundamental Yang mempengaruhi Price Earning Ratio(PER) pada Perusahaan yang terdaftar di JII tahun 2001-2006. Skripsi. Jogjakarta

Hayati, N. (2010). Faktor - Faktor Yang Mempengaruhi Price Earning Ratio (PER) Sebagai Salah Satu Kriteria Keputusan Investasi Saham Perusahaan Real Estate Dan Property Di Bursa Efek Indonesia. JURNAL.

Heveadi, A. N., \& Maewan A. S. W. (1999). Price Earning Ratio (PER) Model Consistency: Evidence from Jakarta Stock Exchange, Kelola Gadjah Mada University Business Review (September).1: 85-97.

Husnan, S. (1996). Dasar-Dasar Teori Portofolio dan Analisis Sekuritas Edisi Kedua, AMP YKPN Yogyakarta.

Indonesia. Undang-Undang tentang Pasar Modal. UU No. 8 Tahun 1995, LN No.64 Tahun 1995. TLN No. 3608.

Koten, F. L. (2004). Analisa Beberapa Variabel Fundamental yang Mempengaruhi Price Earning Ratio sebagai Dasar Penilaian Saham Perusahaan yang Listed di Bursa Efek Jakarta, Tesis, Pasca Sarjana Universitas Brawijaya.

Lestari, M. I., \& Sugiharto, T. (2007). Kinerja Bank Devisa dan Bank Non Devisa dan Faktor-faktor yang Mempengaruhinya. PESAT Vol. 2.

Mahmudah (2013). Analisis Faktor-Faktor yang Mempengaruhi Price Earning Ratio dengan Earning Growth Sebagai Variabel Moderating. Universitas Diponegoro. Semarang

Malinda, M. \& Martelena. (2011). Pengatar Pasar Modal. Andi. Yogyakarta.

Munawir, S. (2002). Analisis Laporan Keuangan. Yogyakarta: Liberty.

Purwaningrum, E. (2011). Factors Affecting Price Earning Ratio Of Campany's Share In The Maufacture Sector. Jurnal Ekonomi Dan Bisnis. 10 (1): 47-51.

Ratnaningrum \& Susilowati, H. (2010). Analisis Faktor-Faktor yangMempengaruhi PER antara Saham yang Tercatat dalam Index Syariah danSaham Biasa. (Studi pada Perusahaan Non Keuangan di 
Bursa EfekIndonesia 2006-2008). BENEFIT Jurnal Manajemen dan Bisnis. 14(1): 1-12.

Rasuli, L. O. (2009). Analisis factor - factor yang mempengaruhi Price earning ratio sebagai dasar penilaian saham (studi empiris pada perusahaan manufaktur di BEI). Thesis. Gorontalo

Rahma, E. Y. (2014). Analisis Variabel Fundamental yang Berpengaruh Terhadap Price Earning Ratio (PER) Sebagai Dasar Penilaian Saham Pada Perusahaan Automotive and Allied yang Terdaftar di Bursa Efek Indonesia. Thesis. Universitas Brawijaya. Malang

Resmi, Siti (2002). Keterkaitan Kinerja Keuangan Perusahaan dengan Return Saham. KOMPAK (September). (6): 275 - 300.

Ridwan S. S. \& Inge B. (2002). Manajemen Keuangan. Jilid 1, Edisi 4, PT. Prehalindo, Jakarta.

Safitri, A. L. (2013). Earning Per Share, Price Earning Ratio, Return On Asset, Debt to Equity Ratio dan Market Value Added terhadap Harga Saham dalam Kelompok Jakarta Islamic Index. Jurnal. Universitas Negeri Semarang. Semarang

Sharpe, W. F., \& Alexander J. G. (1997). Fundamental of Investment, Prentice Hall Inc. Engelwood Cliffs New Jersey.

Sijabat, F. D. \& Anak A.G.S. (2018). Pengaruh DPR,DER, ROA, \& ROE Terhadap Price Earning Ratio Pada Perusahaan Manufaktur. Thesis. Bali.

Sugiyono. 2005. Metode Penelitian Bisnis. Bandung: CV Alvabeta

Sartono, A. (2001). Manajemen Keuangan : Teori \& Aplikasi. Yogyakarta: BPFE.

Sunariyah (2006). Pengantar Pengetahuan Pasar Modal, Edisi 5, UPP AMP YKPN Yogyakarta.

Syamsuddin, L. (2001). Manajemen Keuangan Perusahaan, PT. Raja Grafindo Persada, Jakarta.

Tandelilin, E. (2010). Portofolio dan Investasi Teori dan Aplikasi. Edisi pertama. Yogyakarta: Kanisius

Umar, Husein. (2003). Metodologi Penelitian: Aplikasi Dalam Pemasaran. Jakarta: Gramedia Pustaka Utama.

Yumettasari, Putri, et al. (2008). Analisis Faktor- Faktor yang Mempengaruhi PER antara Saham Syariah dan Saham Non Syariah (Studi Empiris pada Perusahaan Non Keuangan yang Terdapat di BEI Periode 2003-2005).Jurnal Universitas Diponogoro. Semarang. 